The distinctions upon which Dr. v. Haast relies are chiefly the result of the comparison of the skull with a small figure of $M$. layardi quite inadequate for the purpose, and disappear on more rigid examination. For instance, the proportion of the height to the length of the lower jaw, one of Dr. v. Haast's most telling characters, is really identical, instead of being so widely different as supposed. The habitats of the two specimens, instead of being a reason for separating, would rather, in my opinion, be one for uniting them, as there can be no possible barrier for a Cetacean between the seas of the Cape and those of New Zealand. I am therefore unable, upon the evidence before us, to accept Mesoplodon floweri as a well-established species. The great interest of the present communication is that it contains a description of the entire skeleton, and shows that it presents an exceedingly close resemblance to the wellknown Northern form, M. sowerbiensis.

\title{
5. On Mystacina tuberculata.
}

By G. E. Dobson, M.A., M.B., F.L.S., \&c.

[Received May 13, 1876.]

'There are some important points in the external structure of that most remarkable species of Bat, Mystacina tuberculata of New Zealand, which have not yet been noticed, although one writer has occupied four closely printed pages of an octavo book in describing it.

In a paper by Mr. R. F. Tomes, in our 'Proceedings' for 1857, p. 139, a coloured lithograph of this species is given, showing the very peculiar structure of a portion of the wing-and interfemoral membrane near the body; and in the text accompanying it are the following remarks:- "The portions of membrane contiguous to the forearm, the sides of the body, and the tibia are very thick and leathery, with numerous deep wrinkles; and the basal half of the interfemoral membrane (as far as to where the tail becomes free) possesses the same peculiarity. The wrinkles, in many places, cross the legs and forearms, but they are only observable on the upper surfaces of the membranes and limbs. This singular part of the cutaneous system is marked by a regular and decided outline, and can scarcely be said at any place to graduate into the smooth (and very thin) membrane of the wings. Its extent is pretty well indicated by the hairy portions of the menbranes in the genus Lasiurus, excepting that it only occupies one half of the interfemoral membrane."

No conjectures are hazarded as to the use of this peculiarly thickened and differently coloured portion of membrane, which occurs in this species alone.

I find that this thickened portion of the wing-membrane is analogous to the thickened portion of the anterior wings in Hemiptera and to the elytra of the Coleoptera.

Among the many peculiarities of structure presented by $M$. tuber- 
culata, none are more remarkable than the presence of a third phalanx in the middle finger, a character in which it differs from all other species of the family (Emballonuridæ) to which it belongs, and agrees with those of a distinct though allied family, the Phyllostomidæ, which are limited to America.

The middle finger consists of a metacarpal bone and three phalanges. The first phalanx, instead of being folded (in repose) upon the dorsal surface of the metacarpal bone (as in the other species of Emballonuridæ) is flexed downwards, inwards, and forwards upon the inferior surface of the metacarpal, carrying with it the corresponding phalanx of the third finger, which lies folde $d$ downwards and forwards, between it and the metacarpal bone; the second phalanx is folded backwards on the first; and the third phalanx is folded forwards on the second. Being thus reduced by this peculiar folding process into the smallest possible space, the wing is then tucked in beneath the thickened portion of the wing-membrane margining the forearm and side of the body, which sheaths and completely conceals the whole wing. The posterior half of the interfemoral membrane, from the point where the tail perforates it, is rolled upwards and forwards beneath the leathery anterior half. With the wing- and interfemoral membranes thus encased, this species is the most quadrupedal of Bats; and the peculiar development of the extremities, which I shall now describe, indicates special powers of progression.

Fig. $a$.

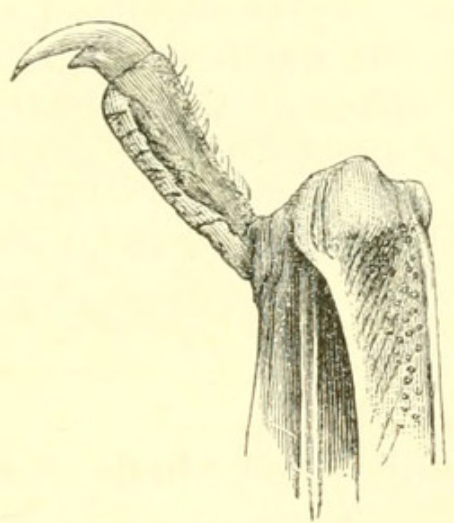

Fig. b.

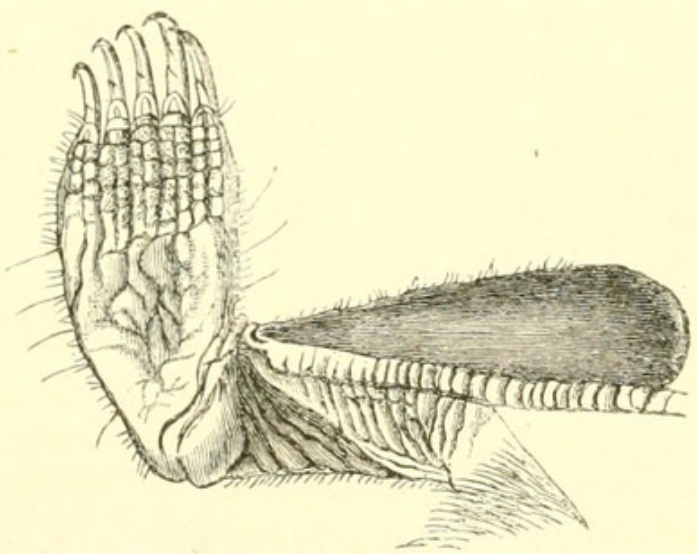

Thumb and sole of foot of Mystacina tuberculata.

The thumb is long, and armed with a large and very acute claw, which has a small talon projecting from its concave surface near the base (fig. a); the feet have similarly long and very acute claws; and at the base of each a similar talon is placed (fig. $b$ ). This peculiar basal talon has not been before observed; and I believe it does not occur in any other species of known Bats. A similar talon is found at the base of the claws in the short-tailed Charneleon, Rhampholeon spectrum, which is thus described by Dr. Günther in his description of that species:- "The tail is so short that it can serve as a prehen- 
sile organ in a very subordinate manner only. This defect is compensated by the development of an additinnal sharp denticle at the inner base of each claw, and of a spine vertically projecting from the flexor side of each finger and toe, which must immensely strengthen the power of the animal for holding on to branches, \&c."

The posterior extremities are short, the legs very short and thick; and the outer and inner toes are shorter and much thicker than the others, as in Nyctinomus; but they are not fringed with long hairs. The feet are remarkably large, and much rotated outwards and forwards, so as to allow of easy progression. The structure of the sole of the foot and of the inferior surface of the leg is very peculiar, and is well shown in the accompanying woodcut (fig. b). The plantar surface, including the toes, is covered with soft and very lax integument, deeply wrinkled; and each toe is marked by a central longitudinal groove with short grooves at right angles to it, as in the genus Hemidactylus (Geckotidæ). The lax wrinkled integument covering the sole of the foot is continued along the inferior flattened surface of the ankle and leg.

All these peculiarities of structure must accompany some corresponding peculiarities in the habits of this species. As the denticle at the base of the claw in Rampholeon spectrum evidently compensates that animal for the shortness of its tail, which is so effective a prehensile organ in other Chameleons, so I have no doubt the denticle at the base of the claw in Mystacina tuberculata compensates that species exceptionally for the imperfect condition of the fore limbs as organs of prehension; and this, taken into consideration with the peculiar manner in which the wings are protected from injury when not employed in flying, and with the manifestly adhesive nature of the sole of the foot and inferior surface of the legs, lead me to believe that this species hunts for its insect food, not only in the air, but also on the branches and leaves of trees, among which its peculiarities of structure most probably enable it to walk about with security and ease.

6. Descriptions of five new Species of Land-Shells from Madagascar, New Guinea, Central Australia, and the Solomon Islands. By Henry Adams, F.L.S., and George French Angas, C.M.Z.S. \& F.L.S.

[Received May 29, 1876.]

\section{(Plate XLVII.)}

Helix malantensis, n. sp. (Plate XLVII. figs. 1, 2, 3.)

Shell imperforate, trochiform, rather solid, faintly obliquely striated, whitish, ornamented with several broad or narrow fulvous or dark chestnut bands, brown at the base; spire turbinate; whorls

* P. Z. S. 1874, p. 443, with a woodcut. 


\section{$2 \mathrm{BHL}$ Biodiversity Heritage Library}

Dobson, G. E. 1876. "5. On Mystacina tuberculata." Proceedings of the Zoological Society of London 1876, 486-488.

https://doi.org/10.1111/j.1096-3642.1876.tb02589.x.

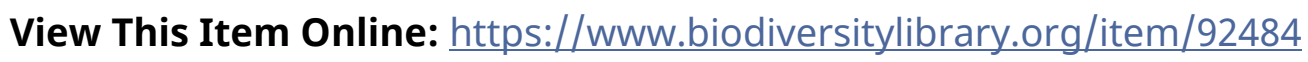

DOI: https://doi.org/10.1111/j.1096-3642.1876.tb02589.x

Permalink: https://www.biodiversitylibrary.org/partpdf/73605

\section{Holding Institution}

Smithsonian Libraries

\section{Sponsored by}

Smithsonian

\section{Copyright \& Reuse}

Copyright Status: Public domain. The BHL considers that this work is no longer under copyright protection.

This document was created from content at the Biodiversity Heritage Library, the world's largest open access digital library for biodiversity literature and archives. Visit BHL at https://www.biodiversitylibrary.org. 